\title{
Al-Kindī’s Attack on Alchemy and His Perfume Making
}

\author{
Takatomo INOUE*
}

\begin{abstract}
This paper discusses the relationship between alchemy and making "chemically" processed products, such as drugs and perfumes. We look into al-Kindī's understanding of alchemy and description of perfume making to discuss this issue. As for the former, Ibn al-Nadìm's Fihrist mentions his writing on the attack on alchemy, but the original text has been lost. However, his idea is cited in Hâjjjī Khalīfa's Kashf al-Zunūn, so we examine this text to understand al-Kindī's view on alchemy. As for the latter, we specifically examine distillation technique. Before the examination of al-Kindī's text, we review the alchemical meaning of distillation from the texts of Jabirian corpus. Then, we investigate the distillation technique in his perfume making text, Kitāb Kìmiy $\bar{a}^{’}$ al-'Ițr wa-'l-Taṣ 'îdāt to clarify the difference between distillation in perfume making and alchemy.
\end{abstract}

Keywords: al-Kindī, alchemy, kīmiy $\bar{a}^{\prime}$, distillation, natural philosophy

\section{Introduction}

In medieval Islam, alchemy was widely attacked. Some people condemned it as a fraud; other people tried to prove its impossibility through natural philosophical theories. On the other hand, making products through processes like alchemy, such as drugs and perfumes, was widely embraced in the Muslim society. Even though both use the same techniques, it is unclear why one became controversial and the other did not. Unfortunately, only a few studies have tried to answer this question up to now. ${ }^{1}$ Ahmad Y. al-Hassan and Donald R. Hill say "When we look at industrial chemistry in Islam we find that there is not much to be gained by attempting to differentiate between 'alchemy' and 'chemistry'" (al-Hassan and Hill 1986, 133). Their understanding of alchemy implies that as long as the same technology was used, any attempts could be called kimiya $\bar{a}^{>}$regardless of the theoretical background. That is, no matter if one believes in transmutation of metals or not,

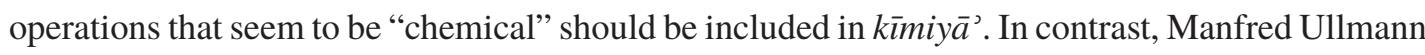
states "Alchemy, however, the art of transmuting metals, has to be singled out from the other more technically oriented professions because of its theoretical foundations" (Ullmann 1979, 110). Martin Levey also indicates the gap between alchemy and practical chemistry from a different perspective. He takes an example of al-Kindī's (d. ca. 866) perfume making and argues that it has little to do with Hellenistic alchemy, which is the main source for Muslim alchemical literature. Rather, he states, "the origins of much of Muslim chemistry are to be sought for Babylonian sources" (Levey 1956, 386), ${ }^{2}$ which means that it has no mysticism, but just practical objectives. He even says that "there may have been intermediaries such as the Egyptians and the Alexandrian

* Graduate Student, Graduate School of Letters, Arts and Sciences, Waseda University

1 Not only regarding this question, shortage of recent researches on alchemy in Arabic literature itself has been pointed out (see Ullmann 1979, 112; Principe 2013,27-28). This situation causes the lack of the consensus between researchers regarding the general picture of alchemy.

2 Levey's argument was based upon the tablet sources in the second millennium of Mesopotamia. 
group of alchemists and others does not affect the importance of Babylonian chemistry" (Levey 1956, 386).

The view of al-Hassan and Hill might make sense if we focus on the technology. It may be true that, from the viewpoint of the alchemists such as Jābir ibn Hayyān, who discusses practical subjects as well as the transmutation of metals, ${ }^{3}$ any subjects can be considered as the parts of $k \bar{\imath} m i y \bar{a}$ '. However, we do not have enough proof that such a "chemical" technology was generally regarded as kimiya $\bar{a}^{\prime}$. In fact, many Muslim intellectuals, such as al-Kindī, Ibn Sīnā and Ibn Khaldūn, had attacked alchemy, that is, they denied kimiy $\bar{a}^{2}{ }^{4}$ It is unlikely that they considered the technology for practical purpose to be within the field of kimiy $\bar{a}^{2}$.

Conversely, Ullmann's argument could describe the viewpoint of those who criticize alchemy. As Ullmann says, "The dispute was above all enacted in the theoretical field," they scarcely attack the technology itself or its practical usage. We can hardly consider that they regard the technology like perfume making as kimiy $\bar{a}^{2}$. However, as indicated, it is uncertain if his argument can describe the alchemists' viewpoint.

Levey seems to have a biased view regarding "chemical" technology. Because he emphasized the oral transmission of the technology, we might assume that the local Mesopotamian tradition was strong enough to survive independently. However, it seems more reasonable to think that technologically, local tradition and Hellenistic alchemy had been fused around the time of alKindī. One of the reasons is that the alchemist Muhammad Zakarīyā al-Rāzī (d. 925) — though he flourished approximately half a century later than al-Kindī- implies that some of the devices for perfume making and alchemy are the same. 5

In this paper, we further investigate the relationship between those two areas of knowledge, which has been left ambiguous in previous studies. We partly follow Ullmann's position regarding the distinction on the basis of theoretical foundations, so we basically suppose that it is impossible to say that making chemical products and alchemy are indistinguishable. However, this paper just focuses on the view of those who attack alchemy, since it is difficult to discuss that of alchemists together. As discussed, alchemists can distinguish them differently. While it is also necessary to investigate the view of alchemists, more studies are needed to resolve this issue, which should be left as a future task. Furthermore, although we assume Ullmann's distinction, we also have to keep in mind the fact that the technology used for the practical and alchemical purpose was often the same. Thus, in this paper, we also take into account some aspects in common between the practical and alchemical, which is missing in Ullmann's viewpoint.

\footnotetext{
Holmyard says, “Though Jabir's main alchemical preoccupation was that of all alchemists, namely to convert inferior metals into gold, he did not neglect to record chemical observation that seemed to him interesting or useful" and "describes processes for the preparation of steel and the refinement of other metals, for dyeing cloth or leather, for making varnishes to waterproof cloth and protect iron from rusting, for mordanting fabrics with alum, and for making an illuminating ink from 'golden' marcasite to replace the much more expensive one made from gold itself' (Holmyard 1957, 81).

4 According to Ibn al-Nadīm's Kitāb al-Fihrist, al-Kindī wrote an "epistle on the warning against the cheating of the alchemists (risālatuhu fì al-tanbīh 'alā khida' al-kīmiyà'̄inn)" (Ibn al-Nadīm 2009, 2:193). Ibn Sīnā attacks alchemy in his Kitāb al-Shifā" (see Ibn Sīnā 1927, 40-42). Ibn Khaldūn wrote a section called "A denial of the effectiveness of alchemy. The impossibility of its existence. The harm that arises from practicing it" (Ibn Khaldūn 1967, 3:267).

5 Al-Rāzī said, "Cucurbit and alembic are things in which rose water is processed" (al-Rāzī 1927b, 414). Cucurbit and alembic are the devices for distillation (see Figs. 1 and 2).
} 
In order to discuss this issue, we look into the case of al-Kindī, who wrote treatises both on anti-alchemy and on perfume making. In this paper, first, al-Kindī's anti-alchemy statement is examined. Although his original text has been lost, Hâjjjī Khalīfa (d. 1657), in his encyclopedic work, Kashf al-Zunūn 'an Asāmī al-Kutub wa-'l-Funūn, cites al-Kindī's anti-alchemy argument. Second, his description of perfume making is discussed. Particularly, his method of distillation of perfume water is investigated. Distillation is one of the most common techniques both in alchemical operations and perfume making, which can be investigated comparatively. After we review the alchemical meaning of distillation through some of the works attributed to Jābir ibn Hayyān, the so-called Jabirian corpus, we look into the distillation of perfume water in al-Kindī's Kitāb Kìmiyä’ al- 'Ițr wa-'l-Taṣ ‘̄idàt.

Previous studies have not revealed important facts on alchemy in medieval Islam, that is, until now, no one has provided an adequate answer to what is alchemy in this period. This paper will contribute to the improvement of the vague understanding through the clarification of the distinction between alchemy and the "chemical" technology.

\section{Al-Kindī's Denial of Alchemy}

Al-Kindī has been recognized as a philosopher who established the basic learning of ancient sciences including Greek philosophy in the Islamic world. Sabra points out that "his project was one of the most daring educational programmes anyone could have conceived in the third/ninth century, (...) al-Kindī’s project also constituted his most important contribution. For, not only was he able to put this seemingly implausible programme into effect, but it turned out to be immensely successful" (Sabra 1993, 606). In his process of organizing Islamic philosophy and science, how was alchemy treated? In fact, al-Kindī appears to be reluctant to accept alchemy. Although alKindī had studied vast kinds of disciplines, including Greek philosophy, mathematics, natural science, craftworks and so forth, why did he take a negative attitude against alchemy?

Most of al-Kindī's works have been lost, so we cannot have enough access to the sources to draw the whole picture of his ideas. Although it is difficult to rely on the primary sources, we can find some hints for al-Kindī's attitude toward alchemy from the secondary historical sources.

Ibn al-Nadīm, a bookseller in the tenth century, in his book catalogue called Kitāb al-Fihrist, mentions al-Kindī and his works. He listed 242 titles of al-Kindī's works, which are divided into seventeen categories. ${ }^{6}$ The key word, "alchemy" (kimiy $\left.\bar{a}^{\prime}\right)$ appears in the category of miscellaneous topics. One of the two titles which include that word is "his epistle on the alchemy of perfume" (risālatuhu fì kìmiyā’ al- 'itr) (Ibn al-Nadīm 2009, 2:193), which should be identified as Kitāb Kimiyä $\bar{a}^{\prime}$ al-'Itr wa-'l-Tas 'ìdāt. This work is available for us, and it just deals with the methods of preparation of perfume and does not discuss any alchemical theories. It is examined in the latter part of this paper. The other work is "his epistle on the warning against the cheating of the alchemists" (risālatuhu fī al-tanbīh 'alä khida' al-kīmiyā'̄in) (Ibn al-Nadīm 2009, 2:193). This work has been lost, but another part in Kitāb al-Fihrist also suggests that al-Kindī was trying to

\footnotetext{
${ }^{6}$ Philosophy (falsafìya), logic (mantiqūya), arithmetic (hisābīyāt), spherics (kurrīyāt), music (mūsīqīyāt), astronomy (nujūmīyāt), geometrics (handasīyāt), cosmology (falakīyāt), medicine (tibbīyāt), astrology (ahkāmīyāt), disputations (jadalīyāt), psychology (nafsīyāt), politics (siyāsiyāt), ontological occurrences (ahdāthīyāt), distances $\left(a b^{\complement} \bar{a} d \bar{l} y \bar{a} t\right)$, premonitions (taqaddumīyāt) and miscellaneous topics (Ibn al-Nadīm 2009, 2:184-194).
} 
deny alchemy through his writing. In the tenth chapter of Kitāb al-Fihrist, the chapter on alchemy, Ibn al-Nadīm introduced "the book of the refutation against al-Kindī on his refutation against the crafts (of alchemy)" (kitāb al-radd 'alā al-Kind $\overline{~ f i ̀ ~ r a d d i h i ~ ' a l a ̄ ~ a l-s ̦ i n a ̄ ' a) ~(I b n ~ a l-N a d i ̄ m ~ 2009, ~}$ 2:460) as one of the alchemical work of Muhammad Zakarīyā al-Rāzī, an influential alchemist in the tenth century. ${ }^{7}$ His writing also has been lost.

Indeed, how al-Kindī attacked alchemy remains unknown just through Ibn al-Nadīm's description. However, when we look at a source in the later period, we can assume what al-Kindi argues. Hạjjī Khalīfa (d. 1657) is an Ottoman scholar in the seventeenth century. His Kashf alZunūn 'an Asāmì al-Kutub wa-'l-Funūn is a bibliographical dictionary, which deals with various disciplines regardless of Islamic or non-Islamic. In the entry of alchemy in Kashf al-Zunūn 'an Asāmī al-Kutub wa-'l-Funūn, Hājjì Khalīfa mentions al-Kindī's refutation of alchemy, saying that "Ya'qūb al-Kindī also composed an epistle on its invalidity, in which he put two treatises" (Hâjjjī Khalīfa 1964, 5:271). This epistle is probably the same as the epistle which Ibn al-Nadīm introduced. He also mentions al-Rāzī’s refutation against al-Kindī’s refutation (Hājjī Khalīfa 1964, 5:271). Furthermore, he also explains what al-Kindī argued.

Ya ${ }^{c} q u \bar{b}$ al-Kindī mentioned in his epistle the impossibility of men's work because nature is independent of their work, cheating of the people of this craft and their ignorance. $\mathrm{He}$ invalidates the claim of those who claim tincturing gold and silver. The deniers (of al-Kindī) said that if artificial gold was the same as natural gold, then what was made through the craft is the same as what is made through nature. If one permitted the possibility that what was made naturally is the same as what was made artificially, we would find a naturally made sword, throne, or ring. That is not true. They also said of tincturing (sābigh) gem: either that it is more enduring against fire than the tinctured (maşbügh), ${ }^{8}$ or that the tinctured is more enduring, or that both are equal. If the tincturing is more enduring, the tinctured has to perish before the tincturing. If the tinctured is more enduring, the tincturing has to perish, and the tinctured remains in its first state free from the color (sibgh). If they are equal in endurance against fire, they are made from the same one genus in order for them to be equal in the endurance against fire. Thus, each of them is not the tincturing nor the tinctured. (Hājji Khalīfa 1964, 5:274-275)

In this argument, there are two discussions. As for the first point, this passage emphasizes the distinction between the thing which is naturally made and that which is artificially made. This idea

\footnotetext{
Stapleton et al. point out that the information in the chapter on alchemy in the tenth century encyclopedic work, Mafātīh al- 'Ulūm by Aḥmad ibn Yūsuf al-Khwārizmī is mainly from al-Madkhal al-Ta' $\bar{l} \bar{\imath} m \bar{\imath}$, an alchemical treatise by al-Rāzī (Stapleton et al. 1927, 319).

8 Holmyard points out "Colour, in fact, to the alchemists was the most important characteristic of a metal and so we find throughout Greek alchemical literature an insistence on colour-changes and sequence of colour-changes that left its mark on all subsequent alchemy. The underlying idea seems to have been that since the prime matter was the same in all substances, an approximation to this prime matter should be the first quest of alchemy; when such a substance had been obtained, it was to be successively impressed with 'pure qualities which one after another should gradually rise in the scale of metallic virtue' to the perfection of gold" (Holmyard 1957, 26). Since the ancient time, separation of the matter which dyes and the other part had been a crucial process in alchemical theories to make a different kind of metal from one kind of metal.
} 
probably stems from the Peripatetic concept of artifacts. Aristotle classified existing objects into natural objects and artifacts by the teleological difference. He defined an artifact as an object made for a specific purpose. ${ }^{9}$ Al-Kindi probably applied this definition ${ }^{10}$ and highlighted the impossibility of natural objects to be artifacts as one of the reasons why natural and artificial gold could not be the same. As for the other, he employed another Peripatetic natural philosophical theory to refute alchemy. As al-Fārābī says in the citation of Aristotle in his work on alchemy, "gold, silver and every gem, which fire does not burn up" (al-Fārābī 1951, 78), in the Peripatetic theory, nothing will be lost even if the fire burns metals. In this passage, those who believe the possibility of alchemy suppose that the metals are in the condition in which "the tincturing" endures fire as much as "the tinctured." They tried to fulfill both of the conditions that metals do not burn, and that "tincturing" and "tinctured" are separable, in order to change the kind of metal by altering their combination. Al-Kindī refutes them by arguing that even if there exist "the tincturing" and "the tinctured," in the case that they are equally endurable against fire, those cannot be regarded as different things since that equality of endurability defines them as the same genus. Therefore, he would say, there are no such separable components as "the tincturing" and "the tinctured" in a certain metal, which can define its quiddity. ${ }^{11}$

One of the two arguments by al-Kindī suggests the impossibility of reproduction of natural objects artificially. The first half of the passage discusses the invalidity of alchemy by the distinction between natural objects and artifacts. This distinction may also suggest the distinction between alchemy and manufacture. He argues that alchemy should be denied because of the pursuit of a natural object in an artificial way. However, manufacturing practical products just intends making artificial objects. Thus, it is probable that he does not regard it as alchemy even if the same apparatus as alchemy is used. Another argument of his tries to show the invalidity of alchemists' understanding of natural philosophical theory and the incoherence of the theory of transmutation of metals. Here he focuses just on the phenomenon of the natural objects, and he seems to ensure the impossibility of the transmutation even if it were a natural phenomenon independent from human arts.

Both arguments are discussed within the framework of Peripatetic philosophy. Muslim philosophers and intellectuals after al-Kindī also discuss in a similar way when they try to prove the invalidity of alchemy. On the other hand, many of Muslim alchemists also employ Peripatetic theory in their alchemical theory. How are the conclusions so different? Clarifying the difference between the role of Peripatetic theory for alchemists and non-alchemists would be the future research task.

9 Hilpinen points out that "Aristotle divided existing things into those that 'exist by nature' and those existing 'from other causes,", and he makes "a distinction between natural objects and artifacts." Artifacts are "products of the art of making things. The art of making something involves intentional agency; thus an artifact may be defined as an object that has been intentionally made for some purpose" (Hilpinen 2011).

${ }^{10}$ Most of al-Kindī's works on natural science has been lost, but it is considered that his philosophical view was basically influenced by Aristotle and his commentators in the Hellenistic period (see Adamson 2005).

${ }^{11}$ It can be found out from one of the objections to al-Kindī's opinion in Kashfal-Zunūn 'an Asāmī al-Kutub wa-'l-Funūn that al-Kindī tries to prove the impossibility of defining quiddity by "the tincturing" and "the tinctured." It says that "Of the equality between the tincturing and the tinctured against fire, the equality of them in the quiddity (māhiya) is not required because you can recognize that the two differences contribute to some of the qualities (șifāt)" (Hājjī Khalīfa 1964, 5:276). 


\section{Distillation in Alchemy and Perfume Making}

\section{Distillation in Alchemical Theory: From Jābir's Kitāb Usțuqus al-Uss}

The next two sections focus on the technology. Specifically, distillation technique in the alchemical literature and al-Kindī's work are compared. In this section, we explore the meaning of distillation in alchemical operations. To do so, we will look into the description about distillation in the Jabirian corpus. The Jabirian corpus is a collection of writings which are attributed to Jābir ibn Hayyān (d. 815). According to Kraus, almost 3,000 works are written under the name of Jābir, but how many works were written by historical Jābir have remained unknown. ${ }^{12}$ As Holmyard points out that "Islamic alchemy never surpassed the level, it attained with one of its earliest exponents, Jabir ibn Hayyan" (Holmyard 1957, 68), the Jabirian corpus significantly influenced alchemical thought in medieval Islam.

In this paper, one of the works of this corpus, called Kitāb Ustuqus al-Uss (The Book of the Element of the Foundation), is examined. Kitāb Ustuqus al-Uss belongs to The Books of the Hundred and Twelve (Kutub al-Mi'a wa-'l-Ithnā 'Ashr), one of the greatest and oldest works of Jabirian corpus. Kitāb Ustuqus al-Uss has three parts ${ }^{13}$ and their commentaries. ${ }^{14}$ As Stapleton et al. mentioned, Kitāb Usțqus al-Uss is "very difficult to understand" (Stapleton et al. 1927, 338), summarizing the discussion there might be uncertain, except to say that it is a part of The Books of the Hundred and Twelve, in which "each dealing with a particular issue of alchemical practice," and "one of the favored themes is the explanation of the symbolic names in the ancient time" (Kraus 1942-43, 1:11). Nevertheless, in Kitāb Usțqus al-Uss and its commentary, we can find some passages which mention distillation as one of the processes for making an elixir, ${ }^{15}$ and those are examined below. Although it is not possible to say that those descriptions of distillation are the standard ones in alchemy in medieval Islam in general since the "way theories are built up differs considerably from one author to other and even in" the Jabirian corpus (Ullmann 1979, 113), we can locate the role and the function of distillation in the alchemical practices from those texts.

Distillation in Arabic uses the root $q-t-r$ or $s-^{c}-d$, meaning drip or drop and rise or ascend, the process was usually called taqtīi or $\operatorname{tas}^{i} \bar{l} d$. The preference of the word depends on the texts and the authors. In Kitāb Ustuqus al-Uss, the words which have the root $q-t-r$ are often used. In the third treatise of Kitāb Ustuqus al-Uss, the methods of distillation are introduced.

\footnotetext{
${ }_{12}$ For his philological research of Jabirian corpus, see Kraus 1942-43, vol. 1.

${ }^{13}$ In Ibn al-Nadīm's Kitab al-Fihrist, Usțqus al-Uss al-Awwal and Ustuqus al-Uss al-Thān̄̄ were dedicated to the Barmak family, and Ustuqus al-Uss al-Thālith and the commentary were not mentioned (Ibn al-Nadīm 2009, 2:453). However, Kraus remarks that Kitāb Ustuqus al-Uss probably consists of three parts for several reasons: 1) Commentary (Tafsìr al-Ustuqus) mentions that Kitàb Ustuqus al-Uss consists of three parts, 2) There is an a reference to the third part at the last part of the second part, 3) The third part says that the third part is the last of all and 4) Kitäb al-Fihrist says Kitäb al-Kamāl, the next treatise of Book of the Hundred and Twelve is the third book which is dedicated to the Barmak family. The dedication to them suggests that that book probably should have been replaced with the third part of Kitāb Ustuqus al-Uss (Kraus 1942-43, 1:10).

${ }^{14}$ According to Kraus, just the fragments are left. Although this commentary describes itself as the commentary of all the three parts of Kitāb Ustuqus al-Uss, only the commentary of the third part is left. The last part of that is not commentary, but the part of Kitāb al-Kamāl, the next treatise of The Book of the Hundred and Twelve (Kraus 1942-43, $1: 14-15)$.

${ }^{15}$ Elixir is usually considered to be a compound made from mineral, plants and animal. When an elixir is cast into a base metal, it transmutes into gold (see Ullmann 1979, 113).
} 
Our stone (hajar) does not require one distillation, but different ways of distillations. One of them is with "dryness" (bi-'l-yābis). It is separation (tafșir). One of them is with "moist" (bi-'l-ratb). It is purification (tasfiya). One of them is with dung. One of them is with black ash for cleansing (tanqiya) of greases (adhān), souls (anfās) and tinctures (așbāgh). ${ }^{16}$ (Ibn Hayyān 1928b, 108-109)

The "stone" here might mean any ingredients for the alchemical operation. ${ }^{17}$ Every metal and mineral are categorized under the term "stone" (hajar). Then, Jābir describes the several distillation methods, specifically, heating methods. Dry heating uses direct fire or hot air to heat a vessel, which contains a "stone." Moist heating uses hot water. Dung heating uses the heat of fermentation. For ash heating, the vessel to be heated is placed in another larger vessel filled with ash, which is heated from the underneath. Jābir describes three purposes of distillation: tafșir tasfiya and tanqiya. Although it is difficult to find the exact differences just from this passage and text, we can find some hints from other alchemical writings. For example, in Kitāb al-Asrār by Muhammad Zakarīyā al-Rāzī, the words whose root is $n-q-y$ are used for removing black color from lime and removing pebbles from clay (al-Rāzī 1964, 9-10). On the other hand, the words whose root is $s-f-w$ are used for purification of water and sometimes filtration. As for the word whose root is $f-s-l$, it appears in the commentary of Kitāb Ustuqus al-Uss. That word is explained as extraction of tincture from the "stone" (Ibn Hayyān 1928c, 120). Although those facts tell the difference in the purpose for the distillation, it can be understood that any types of distillation are trying to extract a pure substance from a compound matter.

In the commentary of Kitāb Usțuqus al-Uss, Jābir gives a more detailed description of the role of distillation in alchemical practices.

Our statement: Separating the stone is first. Its separation (tafsīl) has top and bottom. What is on the top is already pure (tuhr). What remains on the bottom is impure (najas). The interpretation of that: I mean separation of stone, that is, distil it for the first distillation (taqtìira). It vaporizes (yusa cidu) white matter. That from our stone after this distillation (taqtīira) is clean (nazîf). There is no necessity for other preparation (of elixir) definitely, or rather the preparation contains it. The meaning of our statement: What remains is at the bottom. It left tincture and grease in the earth from our stone in the cucurbit. Our statement:

\footnotetext{
${ }^{16}$ According to the first part of Kitāb Ustuqus al-Uss, the "stones" are "classified as 'spirits' (arwāh), 'inorganic substances' (ajsām), 'souls' (nufūs) and 'bodies' (Ajsād)" (Ibn Hayyān 1928a, 66; Stapleton et al. 1927, 394). "spirits" and "souls" are volatilized by fire. The diference between "spirits" and "soul" is the greasy property of the substances. Sulfur, grease, arsenic sulphide are classified as "soul." On the other hand, mercury, sal-ammoniac, and camphor belong to "spirit." (Ibn Hayyān 1928a, 66-67; Stapleton et al. 1927, 394-395) As for tincture, Jābir says, "The 'souls' previously mentioned (that is, sulphur, oil and arsenic sulphide) are common to both in the opinion of those who have knowledge of this art (alchemy) and have made researched in it. But men of insight and learning have often stated that sulphur is essential for the red tincture and arsenic sulphide for the white tincture." (Ibn Hayyān 1928a, 69; Stapleton et al. 1927, 396-397) This might mean that tincture is taken out from the substance such as "soul."

17 "Stone" is not literally stone. According to al-Khwārizmī in Mafātīh, "al-Hajar. Among them (i.e. Alchemists), this is anything by which the art (alchemy) can be performed, that is, anything out of which elixir can be made. It is two kinds, animal and mineral. (...) The varieties of minerals ('stones') are, among the 'bodies' (ajsäd), gold, silver, lead, and tin; and among the 'spirits' (arwāh), mercury, zarnīkh (arsenic sulphide), sulphur, and sal-ammoniac" (Stapleton et al. 1927, 367; al-Khwārizmī 1968, 365).
} 
Then, separate the bottom. It has intensified top and bottom of darkness. The interpretation that means that what is in the cucurbit $\left(q a r^{c} a\right)$ is distilled. The tincture and its grease are distilled from our stone, and its earth remains. (...) Our statement: Then, approach the tops. Separate it (our stone) until it becomes top and bottom. The interpretation: Take the air and fire which vaporize from the cucurbit. Then, separate it (our stone), that is, distil it until the fire is removed from the air. (Ibn Hayyān 1928c, 120-121)

This passage describes two purposes of distillation. One separates "stone" into a clean, white thing and the residue. The other separates that residue into tincture grease and earth or dirt. Both intend separation of pure substances and impurities. It also says that purified things go up, and impurities remain in the cucurbit. Another thing to remark is that the process of distillation is one of the preparations of the ingredients for the elixir, so it is not among the main process of the preparation. In the last part of the passage, Jābir mentions the separation of the four elements. In the Peripatetic natural science, fire and air are considered to have the characteristic of rising, while earth and water have that of descending. In saying that what goes down can be distilled, he might mean what rises in the first distillation can also be further separated.

What is pursued through the process of distillation in Kitāb Ustuqus al-Uss is very clear. The purpose is nothing but obtaining pure substances. This function of distillation in the alchemical theory seems to be widely shared and is not exclusive to the Jabirian corpus. In addition, we have already shown that the tenth century alchemist, al-Rāzī mentioned that distillation is for removing blackness or pebbles in his Kitāb al-Asrār. ${ }^{18} \mathrm{He}$ also appears to intend to purify and cleanse the substances in the process of distillation.

\section{Al-Kindī's Distillation in His Perfume Making Text}

Al-Kindī's book on perfume making called Kitāb al-Taraqquq fĭ al-'Ițr or Kitāb Kìmiyā' al- 'Iṭr $w a-' l-T a s^{`} \bar{\imath} d \bar{a} t^{19}$ shows how to prepare perfume by distillation along with the various perfume recipes. This text is usually classified as his non-philosophical treatise but one that deals with technical subjects of particular interests to the ruling classes with whom he was associated, such as the manufacture of glass, jewelry and armor, as well as perfume (Jolivet and Rashed 1979, 122).

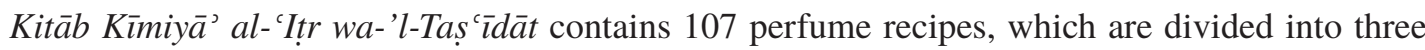
groups by the type of preparation methods. The first group covers the recipes for replacement of particular drugs or drug counterfeiting. The second deals with the recipes for making fragrant oils and ointments. The third introduces the recipes for the distillation of aromatic waters. ${ }^{20}$ In addition to those recipes, the general descriptions of the distillation techniques and apparatuses are inserted in them.

\footnotetext{
${ }^{18}$ Al-Rāzī says, "One of very broad diameter (of alembics), which is suitable for the (removable by) distillation (taqțīr) of the black constituents $(\operatorname{siw} \bar{a} d)$ of substances that have to be calcined, as well as the volatilisation $\left(i s^{c} \bar{a} d\right)$ of salammoniac. The alembic which is not of very broad diameter, and is suitable for the distillation of 'spirits,' and tinctures. The alembic of still less diameter, suitable for the distillation of the 'stone' at the beginning of the operation. The alembic of very small diameter, useful for the distillation ( $\mathrm{radd}$ ) of water, and for its purification (tașfiyah)" (al-Rāzī 1964, 9; al-Rāzī 1927a, 381).

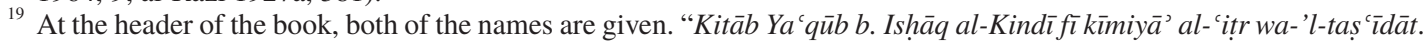
(...) Hādhā kitāb al-taraqquq fì al- 'iṭr” (al-Kindī 1966, 1).
} 


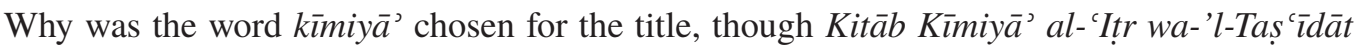
just introduces perfume recipes, and it does not deal with any alchemical theories? It is difficult to reach the certain answer for that, but it is quite possible that al-Kindī did not intend to practice alchemy by the word kimiy $\bar{a}^{2}{ }^{21}$ Rather, al-Kindī might have intended to express the similarity of the motivation of the both practices as Ullmann points out. ${ }^{22}$ Many of the recipes intend selling drugs which are inexpensive to prepare and sell for a high price. Therefore, he says, "I did not think that from this way, there is one better than this, nor finer. It may be mistaken due to the fact even by an excellent reckoning" (al-Kindī 1966, 20), and "It was already sold to a man for a large amount of money" (al-Kindī 1966, 24). As discussed in the previous section, al-Kindī also regards alchemical practices as counterfeit. According to Hạjjī Khalīfa's citation of al-Kind̄̄, in addition to al-Kindī's branding alchemists as cheaters, he does not believe in the claim of alchemists that artificially created gold can be the same as naturally created one. Thus, it can be supposed that alKindī uses the word kimiy $\bar{a}^{\prime}$ to mean the practices of cheating or counterfeit.

Now, we move on to the discussion on the differences between distillation in alchemy and

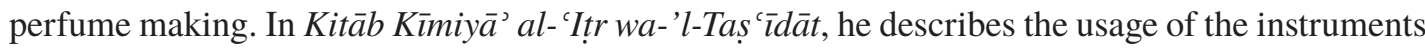
for distillation and the procedure. This instruction is given step by step, and also he indicates some warnings for handling these instruments.

If you put what you want from what we mentioned in the cucurbit (qar $a$ ), then place the alembic $(a n b \bar{l} q)$ on the cucurbit and tighten the connection between it and cucurbit with a band made from cloth whose width is three closed fingers or two. It will be coated with marsh mallow (khitmin) solidly. Then, what connected the cucurbit and alembic is wrapped around the joint. And leave for a while until it dries. Then, earthenware (birām) or pottery (fakhkhār) pot (qidr) is taken, and its size is the height of the cucurbit, and you pour water into the pot. The thing like a ring made of wood on which the cucurbit placed is at the bottom of the pot. And the pot has a cover ( $g h i t \bar{a}^{3}$ ) made of wood, picked its center out by the width of the shape of the cucurbit. This cover is made of two parts, until, when cucurbit is placed in the pot, two halves of the cover are joined at the neck of the cucurbit. Alembic is outside of the cover of the pot. And then, the receiver glass (qābila) is placed at the edge of the delivery tube (ihlīl), which is in the receiver glass. The amount of liquid indicates what is produced in it. This is the figure (Fig. 1).

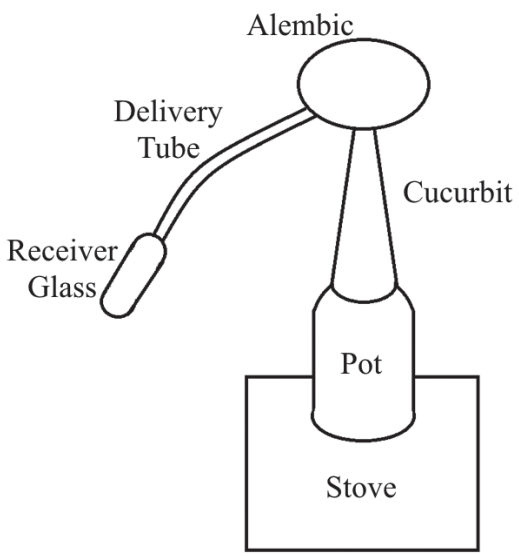

Place of Fuel

Fig. 1: The Illustration of Distillation Apparatus in Kitāb Kīmiy $\bar{a}^{\prime}$ al- 'Ițr wa-'lTașīidāt (moisture)

Drawn by the author based on al-Kindī OR9678/1, fol. $32 b$

If there is a pot and if you want to set more or

less than four cucurbits in the pot, the operation is only one. If the water in the pot is decreased to the point where the water becomes insufficient to cover what is in the cucurbit before all 
the distilling liquid in the cucurbit is gone, increase water into the pot. It should not be cold. It hits the cucurbit, and then it will break the cucurbit. Otherwise, the water in the pot will get cold, and the distilling (qatr $)^{23}$ will cease. Of course, the water which you pour into the pot is hot water, which you pour from the side of the pot. Never hit the cucurbit when you pour water. This is the procedure of the distillation in the

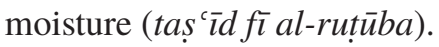

As for when you want to distil in the dryness ( $f i$ al-yabs), let the cucurbit coated with clay, in which dry sifted dung and fine crushed human hair fermented for two or three days are mixed, and with which it is coated after that. The thickness of the clay is one finger. You build this stove for it (the distillation). Indeed, what is distilled in this way is the best. Make its (stove's) fire mild and weak charcoal fire, for the strong fire burn it up and its nourishment $(q \bar{u} t)$, fragrance and taste perish. This is the figure and its simplification (Fig. 2). (al-Kindī 1966, 48-50)

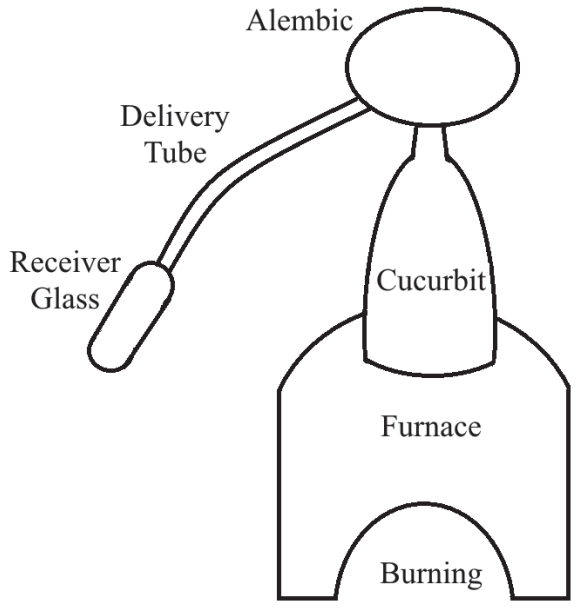

Fig. 2: The Illustration of Distillation Apparatus in Kitāb Kīmiyā' al- 'Itrr wa-'lTaṣì̄āt (dryness)

Drawn by the author based on al-Kindī OR9678/1, fol. 33a

This distillation method of al-Kindī shares many points with the method which other alchemical treatises describe. For example, in the description of al-Rāzì's Kitāb al-Asrār, he mentions 1) the apparatus, which consists of cucurbit, alembic and receiver glass, 2) the height of water in the pot should be the height of the ingredient in the cucurbit, 3) adding water when the water in the pot decreases, 4) the warning about breaking the glass when the cold water is poured into the pot and 5) two ways of heating (water bath and direct coal fire). Furthermore, Ahmad ibn Yūsuf alKhwārizmī, in his Mafātīh al- 'Ulūm, an encyclopedic handbook for secretaries and bureaucrats, says "Among the instruments of the preparation, there are cucurbit and alembic. These are the instruments of rose water manufacturer" (al-Khwārizmī 1969, 256). Al-Rāzī also states in a different treatise, Madkhal al-Ta'limm̄, "Cucurbit and alembic are things in which rose water is processed" (al-Rāzī 1927b, 414). These facts can prove the technological similarity between

\footnotetext{
${ }^{20}$ Throughout these three groups, musk, ambergris, saffron, wars, camphor and other flowers like rose or aromatic trees like sandalwood are used as the main ingredients. As for the recipes that need distillation, there are twenty-eight recipes. The main ingredients for these recipes are camphor (kāfür), citron (utruj), apple (tuffāh), myrtle ( $\bar{a} s)$, bush basil (shähsifaram), saffron (za'frān), musk (musk), khalūq (one of compound perfume), clove (qalanful), cinnamon (qirfa), nard (sanbal), agar wood ( $\left.{ }^{c} \bar{u} d\right)$, sandalwood (sandal), rose (ward) and jasmine (yāsmīn).

${ }^{21}$ It is uncertain that al-Kindī himself used the word " $k \bar{\imath} m \bar{\imath} y \bar{a}$ "” to call the treatise because two titles are given in the text (see footnote 19). However, Kitab al-Fihrist also call this treatise "his epistle on the alchemy of perfume (risālatuhu fi kìmiyā' al- 'itr)" (Ibn al-Nadīm 2009, 2:193), so it appears to be quite possible that "kimmìy $\bar{a}$ " was used in his original writing.

${ }^{22}$ Ullmann states that "[t]he title Kimmiy $\bar{a}$ ' al- 'Itr which al-Kindī gives to his book on the falsification of perfumes is as metaphorical" (Ullmann 1979, 110).

${ }^{23}$ al-Kindī 1966: 'itrr, al-Kindī OR9678/1: qatrr.
} 
perfume making and alchemy.

If we pay attention to the heating method, al-Kindī's distillation methods have similarities even to those of Jābir discussed in the previous section. Jābir made a contrast between heating with a water bath and without by the expressions of moist (ratb) and dryness ( $y \bar{a} b i s$ ). In the same way, al-Kindī uses in Kitāb Kìmiyā' al- 'Itrr wa-'l-Taș 'ìdāt the expressions "distillation in the moisture" ( fi al-rutūba) and "distillation in the dryness" ( $f \bar{\imath}$ al-yabs). These common terminologies suggest that perfume making and alchemy not only use similar methods, but they may share the basic technological methodology.

Using those techniques, al-Kindī shows the way to prepare rose water in Kitāb Kìmiy $\bar{a}^{3}$ al-'Itr wa-'l-Taș 'ì $\bar{l} \bar{a} t$. In the direction of distillation of rose water, despite the similarity in the technological side, al-Kindī implies a contradiction to the alchemical theory.

You take a red rose which you want. You remove the stem. I mean, a fresh and juicy red rose and the center of the petal. And leave it for a while. Then, fill it in the cucurbit through the neck. Alembic is set and is distilled in the moisture ( $f \bar{\imath}$ ruțūba). If you want to make your own rose water, this (rose water), descending from alembic, can be dyed red like the rose. When you pour on a man, it dyes his clothes. Whenever it drys up, the redness on the clothes will be gone. At the point when all of it is dried up completely, its red color is gone from the clothes and the white clothes return to the condition which it was, and the fragrance remained in the clothes.

When the cucurbit is filled with rose petals, fill it well and also fill the alembic with rose petals. The alembic is set on the cucurbit. After that distil it in the moisture. Then, it will make red water descend like what we described. We can operate it more than one time. If you want to make it red with the color as the blood of a gazelle, You take a twig of 'a qir samqā or anchusa (sankār) which is good, not rotten. Moisten it with water for an hour. Then wrap it in cotton. The cotton is inserted from the entrance into the delivery tube of the alembic, which is not difficult, but do not make the insertion of the cotton tight. Then the alembic is set on the cucurbit and distil it in the moisture as we said. Just after rose water passed this cotton, it receives the red tincture (sibgh) from it, and red rose water will descend. Its effect on the clothes, when it is poured to the clothes, is like the first one. If you wrap the piece of the inside of the herb called amaranth (bustān aburūz), that performs the effect of redness. If you make the strings of saffron (za farān) in this cotton, (rose) water will pull out yellow color. If you make the leaf of crushed alfalfa (ratba) in this cotton, (rose) water will pull out green color. It works like the red (case) in the clothes. Like that, the yellow (case) works too. These are the very elegant sections of the operation of rose water. (al-Kindī 1966, 57)

In most of the part, al-Kindī discusses the coloring of rose water. He is trying to add some colors to it during the process of distillation. This direction should not agree with the role of distillation in the alchemical theory which Jābir and al-Rāzī propose. According to Jābir, as mentioned in Kitāb Ustuqus al-Uss, distillation intends separation, purification or cleansing, which is contrary to adding some tincture to rose water. Although the meaning of "tincture" could be different between 
Jābir and al-Kindī, Jābir uses distillation for extraction of tincture from an impure compound, while al-Kindī's method produces a compound of tincture and rose water. Al-Kindī's coloring of rose water seems to show his neglect of the alchemical theory and framework.

Al-Kindī's distillation, on the technological and methodological level, appears to be the same as that of alchemy, on the other hand, on the theoretical level, he did not try to apply the alchemical theory to his own methodology. One of his arguments refuting alchemy is the distinction between natural objects and artifacts. He would consider that perfume is an artificial product, which does not belong to the territory of nature. In other words, the perfume making process should not be the reproduction of a natural object, which requires the knowledge of natural philosophy and according to him, which cannot be accomplished. His distinction between alchemy and manufacturing practical products lies at whether one intends to reproduce a natural object or not

\section{Conclusion}

This paper has explored how al-Kindī makes a distinction between alchemy and "chemical" manufacturing. In the first half, we explored the distinction as represented by al-Kindī's argument cited in Kashf al-Zunūn 'an Asāmī al-Kutub wa-'l-Funūn by Hạjjī Khalīfa. Al-Kindī argues that natural substance cannot be reproduced artificially and that even if we regard the transmutation of metals as an event in nature, the theory of switching "tinctures" (așbāgh) of metal for the transmutation cannot be consistent with his natural philosophical theory. The first point follows Aristotle's definition of the natural object and artifact. For the second point, al-Kindī also seems to apply Peripatetic natural philosophy to the discussion of metallic transmutation. Although he tries to prove the impossibility through two Peripatetic theories, the second proof seems not necessarily crucial if the first one is proven. This is because he no longer considers alchemy as the reproduction of natural objects. Therefore there is no need to apply to the natural philosophical theory. For al-Kindī, the craft of alchemy merely produces artifacts even though alchemists claim it as the reproduction of natural objects. In other words, his interpretation of alchemy is a combination of a craft of artifacts and a wrong theoretical basis.

In the second half of this paper, the distillation methods were compared. Firstly, we determined the usage and meaning of distillation in the alchemical practices from Jabirian corpus. Distillation as an alchemical operation functions as purification or separation of substance, which means the extraction of a simple substance from a mixed or compound matter. On the other hand, when we look at Kitāb Kìmiyā' al-'Itrr wa-'l-Taș 'ìdāt, we found that al-Kindī does not necessarily regard the function of distillation as purification or separation in the case of perfume making. This is because al-Kindī adds colors to rose water during distillation, which indicates that he ignored the alchemical meaning of distillation, even though his method and that in the alchemical literature are almost identical in respect of the instruments, processes and technology. This fact does not contradict what al-Kindī stated in the refutation of alchemy. In his view, perfume making is just a production of an artifact and does not intend a reproduction of a natural object, therefore, it does not require any theoretical basis.

Al-Kindī divided existents into natural objects and artifacts, which seems to be the critical point for the issue between alchemy and "chemical" manufacturing. Peripatetic theory lies at the 
foundation of his view. This seems to happen to other Muslim philosophers and intellectuals, who discuss alchemy. The examination of their understandings on that issue will be the future task of this study, and we have to keep in mind that not all the philosophers regard alchemy as impossible. For example, al-Fārābī discusses the possibility of transmutation from the perspective of the Peripatetic theory. ${ }^{24}$ The way of employing the theory should be different from person to person. At the same time, we have to determine the view of Muslim alchemists on whether they distinguish nature and artifact and on how they relate their theory and Peripatetic natural science, which also require further research. We should take into account the possibility that they had a completely different paradigm for the issue of natural philosophy from that of the philosophers and intellectuals, even though they both applied the Peripatetic theory.

\section{Bibliography}

Adamson, P. 2005: “Al-Kindī,” in P. Adamson and R. C. Taylor (eds.), The Cambridge Companion to Arabic Philosophy, Cambridge, 32-51.

al-Fārābī, Abū Naṣr Muhammad ibn Muhammad 1951: Risālat al-Hakīm al-Fāḍil al-Muṭan al-Muhaqqiq Abī Naṣr alFārābì fì Wujūb Sinā'at al-Kìmiyā, ed. by A. Sa1lı in "Al Fârâbî's Article on Alchemy," Türk Tarih Kurumu Belleten $15,75-79$.

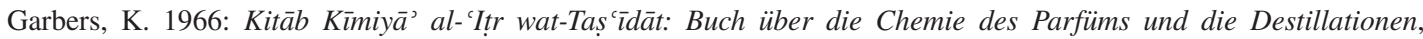
Abhandlungen für die Kunde des Morgenlandes 30, reprint of 1948 ed., Leipzig.

Hạjjī Khalīfa 1964: Kashfal-Zunūn 'an Asāmī al-Kutub wa-'l-Funūn, ed. by G. Fluegel, 7 vols., reprint of 1835 ed., New York and London.

al-Hassan, A. Y., and D. R. Hill, 1986: Islamic Technology: An Illustrated History, Paris.

Hilpinen, R. 2011: “Artifact,” in N. Zalta et al. (eds.), The Stanford Encyclopedia of Philosophy, winter 2011 ed., http:// plato.stanford.edu/entries/artifact/ (accessed November 25, 2016).

Holmyard, E. J. 1957: Alchemy, Harmondsworth.

Ibn Hayyān, Jābir, 1928a: Kitāb Ustuqus al-Uss 'alā Ra’y al-Falāsifa, ed. by E. J. Holmyard, in idem (ed.), The Arabic Works of Jābir Ibn Hayyān: Arabic Texts, Paris, 61-76.

Ibn Hayyān, Jābir, 1928b: Kitāb Usțqus al-Uss wa-Huwa Thālith, ed. by E. J. Holmyard, in idem (ed.), The Arabic Works of Jābir Ibn Hayyān: Arabic Texts, Paris, 99-112.

Ibn Hayyān, Jābir, 1928c: Tafsīr Kitāb al-Usțqus, ed. by E. J. Holmyard, in idem (ed.), The Arabic Works of Jābir Ibn Hayyān: Arabic Texts, Paris, 115-124.

Ibn Khaldūn 1967: Muqaddima, trans. by F. Rosenthal, $2^{\text {nd }}$ ed., 3 vols., London.

Ibn Sīnā 1927: Kitāb al-Shifä', partly trans. by E. J. Holmyard and D. C. Mandeville in idem (eds.), Congelatione et Conglutinatione Lapidum: Being the Section of the Kitāb al-Shifä', Paris, 17-42.

Jolivet, J., and R. Rashed, 1979: "al-Kindī,” in C. E. Bosworth et al. (eds.), Encyclopaedia of Islam, new ed., vol. 5, Leiden, 122-123.

al-Khwārizmī, Muḥammad ibn Aḥmad 1927: Mafātīh al- 'Ulūm, partly trans. by H. E. Stapleton et al., in idem 1927, $363-368$.

al-Khwārizmī, Muḥammad ibn Aḥmad, 1968: Mafātīh al- 'Ulūm, ed. by G. van Vloten, reprint of 1895 ed., Leiden.

al-Kindī, Abū Yūsuf Ya'qūb ibn Isḥāq 1966: Kitāb Kìmiyā’ al- 'Iṭr wa-'l-Taṣ '̌̀āt, ed. by K. Garbers, reprint of 1948 ed., Leipzig.

al-Kindī, Abū Yūsuf Ya'qūb ibn Isḥāq, al-Taraqquq fì al-' Iṭr, MS. British Library Or. 9678/1.

Kraus, P. 1942-43: Jābir ibn Hayyān: Contribution à l'histoire des idées dans l'Islam, 2 vols., Cairo.

Levey, M. 1956: "Babylonian Chemistry: A Study of Arabic and Second Millenium B. C. Perfumery,” Osiris 12, 376-389. al-Nadīm, Abū al-Faraj Muḥammad ibn Ishāa 2009: Kitāb al-Fihrist, ed. by A. F. Sayyid, 2 vols., London.

Principe, L. M. 2013: Secrets of Alchemy, Chicago and London.

al-Rāzī, Muḥammad ibn Zakarīyā 1927a: Kitāb al-Asrār, partly trans. by H. E. Stapleton et al., in idem 1927, $369-393$.

${ }^{24}$ For detailed information on what he discusses, see al-Fārābī 1951, 75-79 and Ibn Khaldūn 1967, 3:272. 
al-Rāzī, Muḥammad ibn Zakarīyā, 1927b: Al-Madkhal al-Ta'līmī, ed. by H. E. Stapleton et al., in idem 1927, $412-417$. al-Rāzī, Muḥammad ibn Zakarīyā, 1964: Kitāb al-Asrār, ed. by M. T. Dāneshpazhūh, in idem (ed.), Kitāb al-Asrār waSirr al-Asrār, Tehran, 1-116.

Sabra, A. I. 1978: "al-Khwārazmī," in C. E. Bosworth et al. (eds.) Encyclopaedia of Islam, new ed., vol. 4, Leiden, 1068-1069.

Sabra, A. I., 1993: "Some Remarks on Al-Kindi as a Founder of Arabic Science and Philosophy,” A. O. Al-Omar (ed.), Dr. Mohammad Abdulhadi Abu Ridah Festschrift, Kuwait, 601-607.

Stapleton, H. E. et al. 1927: "Chemistry in Iraq and Persia in the Tenth Century AD," Memoirs of the Asiatic Society of Bengal 8, 317-418.

Ullmann, M. 1979: “al-Kīmiyā̄,” C. E. Bosworth et al. (eds.), Encyclopaedia of Islam, new ed., vol. 5, Leiden, 110-115. 